\title{
A NEW LYCOPHYTE MIOSPORE SPECIES FROM THE MIDDLE JURASSIC OF IRAN
}

\author{
FIROOZEH HASHEMI-YAZDI, FRESHTEH SAJJADI \\ Faculty of Geology, College of Science, University of Tehran, Enghelab Avenue, Tehran 14155-6455, Iran. \\ fhashemi121@gmail.com,sajjadi@ut.ac.ir
}

\author{
AFSANEH DEHBOZORGI \\ Faculty of Science, Imam Khomeini International University of Ghazvin, Ghazvin, Iran. \\ afsaneh.dehbozorgi@gmail.com
}

\begin{abstract}
A new, morphologically distinctive, lycophyte species from the Middle Jurassic (Bajocian-Callovian) Dalichai and Baghamshah formations of north and central Iran is introduced herein. It is typified by featuring distinct polygonal amb, well-defined margo, and prominent reticulate exine except for the proximal face. The new taxon occurs as minor constituent of diverse, well-preserved palynofloras comprising both marine and land-derived palynomorphs that collectively denote a Middle Jurassic (Bajocian-Bathonian-Callovian) age. The apparent short stratigraphic range and conspicuous morphological attributes of the new taxon likely nominate it as a potentially valuable biostratigraphic index for inter-basinal correlation of Middle Jurassic strata across north and central Iran.
\end{abstract}

Key words: miospores, Retitriletes, Middle Jurassic, Iran.

RESUMO - O presente estudo apresenta uma nova espécie de Lycophyta, morfologicamente distinta, do Jurássico Médio (Bajociano-Caloviano) das formações Dalichai e Baghamshah do Norte e Centro do Irã. Caracteriza-se por ambito poligonal distinto, margo bem definido e exina reticulada proeminente, exceto para a face proximal. O novo táxon ocorre como constituinte menor de diversas palinofloras, bem preservados que compreendem palinomorfos tanto assembleias marinhas como continentais, que denotam em conjunto um Jurássico Médio (Bajociano-Batoniano-Callovian). A curta distribuição estratigráfica e os conspícuos atributos morfológicos do novo táxon, permitem nomeá-lo como um índice bioestratigráfico, potencialmente valioso para a correlação de estratos entre bacias do Jurássico Médio em todo o norte e centro do país.

Palavras-chave: miósporos, Retitriletes, Jurássico Médio, Irã.

\section{INTRODUCTION}

Much potential exists for palynological studies of Mesozoic sequences in Iran, especially for the Triassic and Jurassic strata. Palynological investigations of Jurassic sediments have already been accomplished (e.g. Kimyai, 1968, 1974; Arjang, 1975; Achilles et al., 1984; Bharadwaj \& Kumar 1986, 1988; Sajjadi et al., 2007; Dehbozorgi et al., 2013) in various parts of the country. Jurassic palynomorphs, particularly miospores, from north and central Iran are comparatively better documented.

In east central Iran, investigations have focused exclusively on the coal-bearing Jurassic strata around Kerman. Palynological investigation in the Alborz Mountains in the northern part of the country has been conducted on nearcoeval and mostly coal-bearing sediments similar to those in central Iran.

During routine palynological investigations of Middle Jurassic strata from several localities in north and central Iran, the authors encountered a morphologically distinctive, previously unreported reticulate trilete spore species, which is detailed herein as Retitriletes polygonatus sp. nov.

During routine palynological investigations of Middle Jurassic strata from several localities in north and central Iran a morphologically distinctive, previously unmatched reticulate trilete spore species was encountered. It has been recorded from well-preserved miospore assemblages recovered from the intervals cropping out at four localities in the Alborz Mountains, northern Iran and one locality in central Iran (Figure 1). Because of its short stratigraphic range, the species can be regarded as a biostratigraphic index for the region. The main aim of the present contribution is, therefore, to describe the morphological features of this new taxon and compare it to closely related morphological entities previously known from elsewhere.

\section{LOCATIONS AND GEOLOGICAL SETTING}

Five sections were measured and sampled in detail at Central Alborz Mountains and central Iran (Figure 1). The 


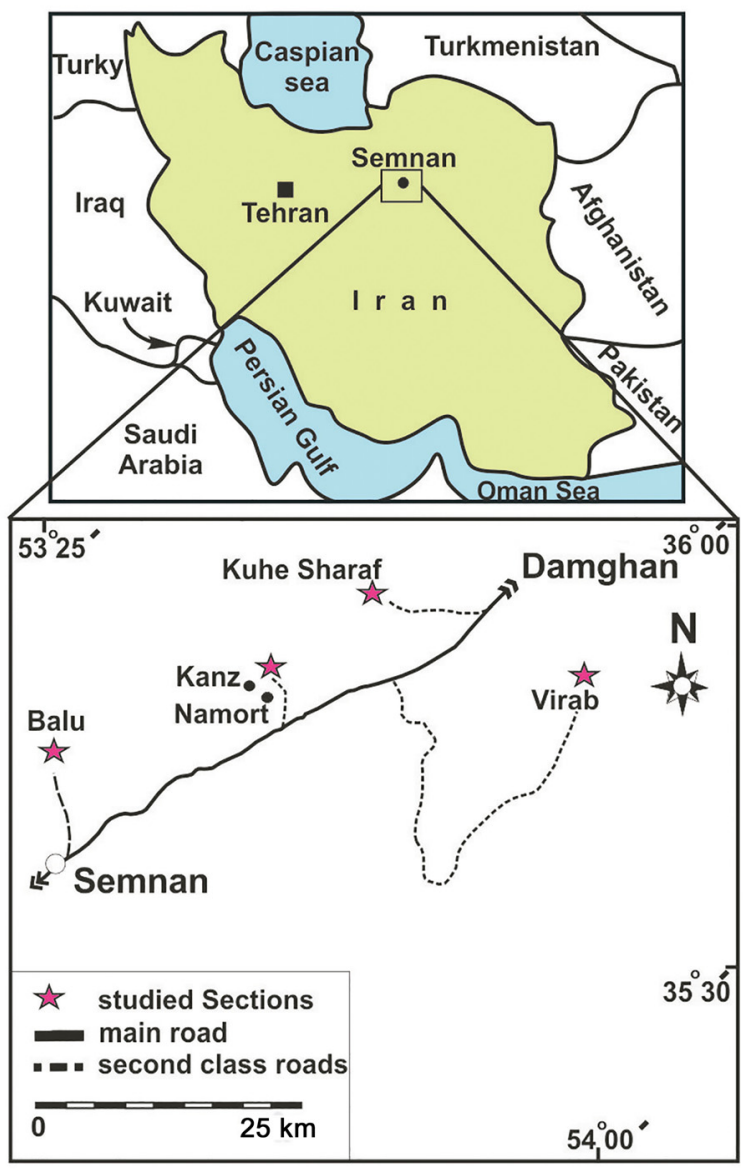

Figure 1. Location map of the studied sections.

Dalichai Formation is well exposed at four localities, the Balu section with a thickness of $594 \mathrm{~m}$, is located in Payambaran area, north of Semnan, northern Iran $\left(35^{\circ} 43^{\prime} \mathrm{N}, 53^{\circ} 26^{\prime} \mathrm{E}\right)$. The other, Lavan section, which reaches $160 \mathrm{~m}$ is exposed at northeast of Damghan $\left(36^{\circ} 22^{\prime} \mathrm{N}, 54^{\circ} 14^{\prime} \mathrm{E}\right)$. Two other sections of Dalichai Formation, one at the Kanz section with a thickness of $292 \mathrm{~m}\left(35^{\circ} 48^{\prime} \mathrm{N}, 53^{\circ} 40^{\prime} \mathrm{E}\right)$, and the other, Sharaf section with a thickness of $217 \mathrm{~m}\left(35^{\circ} 56^{\prime} \mathrm{N}, 53^{\circ} 47^{\prime} \mathrm{E}\right)$, are widely distributed near the area of Jam, Central Alborz Ranges, northeastern Iran. The outcrop of the Baghamshah Formation, the Virab section, with a thickness of $279 \mathrm{~m}$ $\left(35^{\circ} 48^{\prime} \mathrm{N}, 53^{\circ} 59^{\prime} \mathrm{E}\right)$, is located in central Iran.

Iranian geology is classified into a number of diverse tectonostratigraphic units (Stöcklin, 1968). The Alborz Basin is located on the southern border of south Caspian Basin in northern Iran and the Central Iran Basin. The Alborz range has evolved from the Triassic to the present-day during the Cimmeride and Alpine Orogenies (Alavi, 1996) and is situated between the Caspian Sea to the north and the Iranian Plateau to the south (Stöcklin, 1974). The mountains consist of Late Precambrian basement with a Gondwanan affinity, similar to the Arabian-Nubian platform (Hassanzadeh et al., 2002).

The Central Iran Basin is one of the most important and complicated structural zones in Iran and comprises a vast area of the Iranian Plateau. This area was a stable platform during Paleozoic times, but the late Triassic movements caused the creation of horsts and grabens limited by faults and fold-and-thrust belts. According to Stöcklin (1968), central Iran is limited by the Alborz Mountains to the north, Lut Block to the east, and Sanandaj-Sirjan zone to the south-southwest. Central and north Iran (the Iran Plate) occupied a position at the southern margin of Eurasia in the Late Triassic (Seyed-Emami, 2003). Close lithologic and faunistic relationships between North and central Iran during deposition of the Shemshak Group (Late Triassic-Middle Jurassic) indicates that the two areas were palaeogeographically closely related, probably forming a kind of archipelago (Seyed-Emami et al., 2008).

In the Late Bajocian, a widespread transgression caused a new and large sedimentary cycle. This event continued until the end of the Jurassic (Fürsich et al., 2009). The Middle and Upper Jurassic sedimentary successions in north and central Iran comprise five formations including Dalichai, Lar (Alborz) and part of the Badamu Limestone, Hojedk and Baghamshah (central Iran).

The Dalichai Formation is represented by shales, calcareous shales, marls, and richly ammonitiferous limestones (Steiger, 1966), being widely distributed in north Iran. It disconformably overlies the dark, siliciclastic coalbearing Shemshak Formation and underlies gradually the light cliff-forming carbonates of the Lar Formation. In addition to ammonites, a diverse fauna includes belemnites, pelecypods, brachiopods, echinids, sponges, bryozoans, and foraminifera, in the sediments related to this rock unit has been reported from different stratigraphic sections (Alavi-Naini, 1972; Sussli, 1976; Nabavi \& Seyed-Emami, 1977). The ammonites of Dalichai Formation indicate Late Bajocian to Oxfordian age, but there is no place in which the formation includes this total range (Sussli, 1976; Nabavi \& Seyed-Emami, 1977; Seyed-Emami et al., 1985; Schairer et al., 1991; SeyedEmami et al., 1995).

Three of the sections studied are located in the Jam region, eastern Semnan, and partly related to central Iran (Figure 1). One of the distinct structural units influencing the sedimentation pattern throughout the Jam area is the Attari fault which extends in a NE-SW direction. According to AlaviNaini (1972) this fault had a significant role in Jam area and separated it into two different parts, Zone A and Zone B. Zone $A$ is located in the northwestern of the Jam and is associated with Alborz Mountains. Zone B is related to Central Iran Mountains and constitutes most of the Jam in the southeastern part of it (Figure 2). In the Jam area (Zone B) the Parvadeh Formation is followed by the Baghamshah Formation in the Middle Jurassic (Dogger) while at the same time, Dalichai Formation has been deposited in the northwestern of this area (Zone A). In this study, two sections of the Dalichai Formation are located in Zone A and the only section of the Baghamshah Formation is located in Zone B.

Baghamshah Formation is characterized chiefly by alternating of uniform pale-green marly shale, silty to fine sandy, soft-weathering, with a few thin harder layers of sandstone, and minor salt and gypsum content in some horizons. It overlies with transitional contact the underlying 


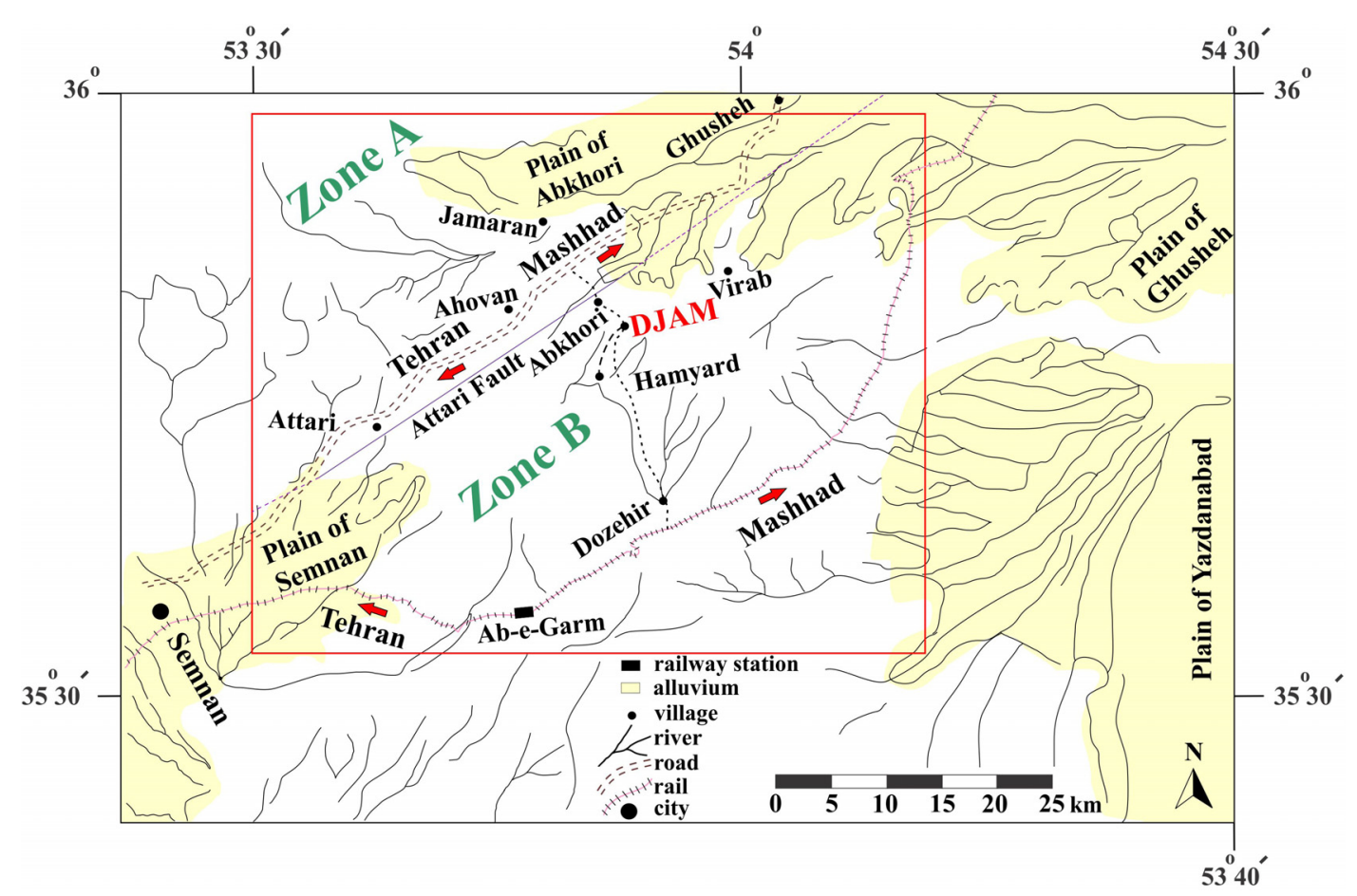

Figure 2. Attari fault location in two structural-sedimentary zones, Alborz and Central Iran in Jam area (modified from Alavi-Naini, 1972).

Parvadeh Limestone, and is topped with a disconformable contact, by the Parpa Limestone. Ammonites of this rock unit are representative of Upper Bathonian to Upper Callovian age (Seyed-Emami et al., 1997, 1998).

\section{MATERIAL AND METHODS}

A total of 170 palynological samples were collected exclusively from five outcrops mentioned above (Figure 3). All samples were prepared following standard palynological processing procedures (e.g. Phipps \& Playford, 1984; Traverse, 2007), including $\mathrm{HCl}(10-50 \%)$ and $\mathrm{HF}(40 \%)$ treatment for dissolution of carbonates and silicates, respectively. Then the residues were saturated with $\mathrm{ZnCl}_{2}$ solution (specific gravity $1.9 \mathrm{~g} / \mathrm{ml}$ ) for density separation. All the residues were sieved with a $15 \mu \mathrm{m}$ mesh sieve prior to making strew slides. Three slides for each preparation were examined by transmitted light microscope. All the strew slides prepared are stored in the collection of Faculty of Geology, Tehran University, Iran catalogued as 1-55 FH.Dl; 1-32 Ka.Dl; 1-26 Sh.Dl; 1-29 La.Dl and 1-28 Vi.B.

\section{ASSOCIATED PALYNOFLORAS AND THEIR BIOSTRATIGRAPHIC SIGNIFICANCE}

Diverse and well-preserved palynomorphs dominated by spores, pollen grains, dinoflagellate cysts, foraminiferal test linings, fungal spores and acritarchs (see Appendix 1 for the taxonomic list) occur in samples of the Dalichai and the Baghamshah formations. Occurrence of miospores species with known vertical ranges include Klukisporites variegatus Couper, 1958, Converrucosisporites pricei McKellar, 1998,
Osmundacidites senectus Balme, 1963, Sellaspora asperata (Dettmann) emend. McKellar, 1998, Concavissimisporites verrucosus Delcourt \& Sprumont emend. McKellar, 1998 and Murospora florida (Balme) Pocock, 1961 collectively indicate a Dogger age according to data offered by such authors as Balme (1964), Arjang (1975), Ashraf (1977), Bharadwaj \& Kumar (1986), Filatoff \& Price (1988), McKellar (1998), Sajjadi et al. (2007), Dehbozorgi et al. (2013). Furthermore, based on the existence of such distinct dinoflagellate cyst species as Meiourogonyaulax valensii (Riding \& Thomas, 1992) base of the succession examined, herein, is considered to be no older than Bajocian. The Bathonian age is confirmed by the presence of Adnatosphaeridium caulleryi (Riding \& Thomas, 1992; Ghasemi-Nejad et al., 2012; Mafi et al., 2013). The relatively low diversity of the contemporaneous dinoflagellate cysts assemblage in the upper part of the succession seems to be consistent with a Callovian age (Ghasemi-Nejad et al., 2012; Mafi et al., 2013).

\section{SYSTEMATIC PALAEONTOLOGY}

Anteturma PROXIMEGERMINANTES R. Potonié, 1970

Turma TRILETES Reinsch emend. Dettmann, 1963

Suprasubturma ACAVATITRILETES Dettmann, 1963

Subturma AZONOTRILETES Luber emend. Dettmann, 1963

Infraturma MURORNATI Potonié \& Kremp, 1954

Retitriletes van der Hammen ex Pierce emend. Döring et al., 1963

1956 Retitriletes van der Hammen, p. 76. (nom. nud.). 1961 Retitriletes van der Hammen ex Pierce, p. 21. 


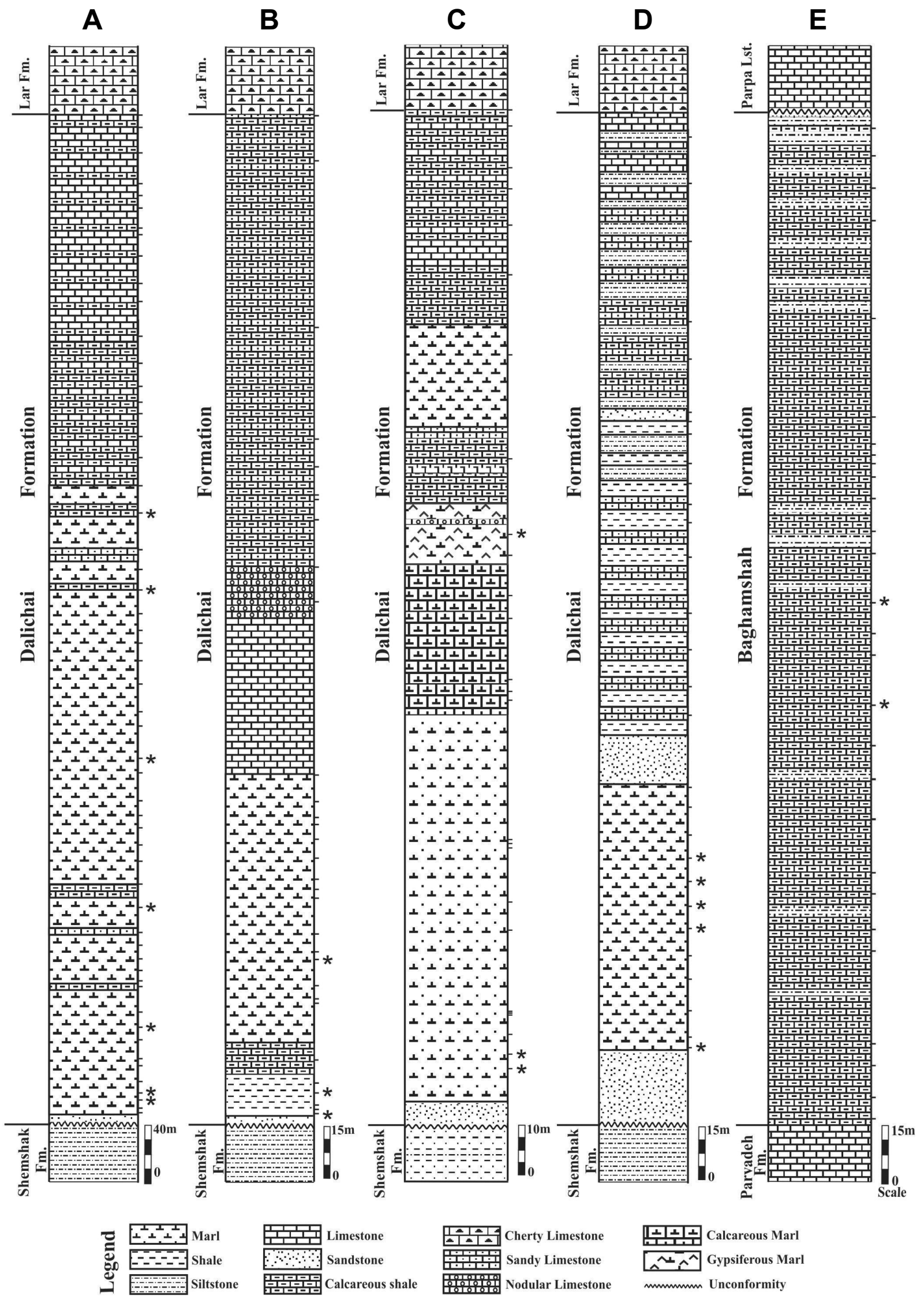

Figure 3. Litostratigraphic columns of the studied sections. A, Balu; B, Kanz; C, Sharaf; D, Lavan; E, Virab. Symbol: *, records of the new species. 
1963 Retitriletes van der Hammen ex Pierce emend. Döring, Krutzsch, Mai \& Schulz, in Krutzsch, p. 8.

Type species. Retitriletes globosus Pierce, 1961; by original designation.

Discussion. Retitriletes van der Hammen ex Pierce emend. Döring et al., 1963 accommodates azonate, trilete miospores with a net like distal reticulum which may be extended proximo-equatorially or to the laesurae termini. The validity of Lycopodiumsporites Delcourt \& Sprumont 1955 and its relationship with other genera have been discussed by Döring et al. in Krutzsch (1963, p. 8), Srivastava (1972, p. 29-30;
1975, p. 56-58) and McKellar (1974, p. 12-13; 1998, p. 99). Döring et al. (1963) considered Lycopodiumsporites to be invalid but Srivastava (1972) and McKellar (1974) accepted it as incorporating azonate, trilete miospores with distal foveoreticulate sculpture.

\section{Retitriletes polygonatus sp. nov.}

(Figures 4A-L; 5A-L)

Holotype. slide FH3/2; Figure 5A-C.

Type locality. Iran, Semnan, Balu section, 20 m, sample 3. Stratigraphy. Dalichai Formation.
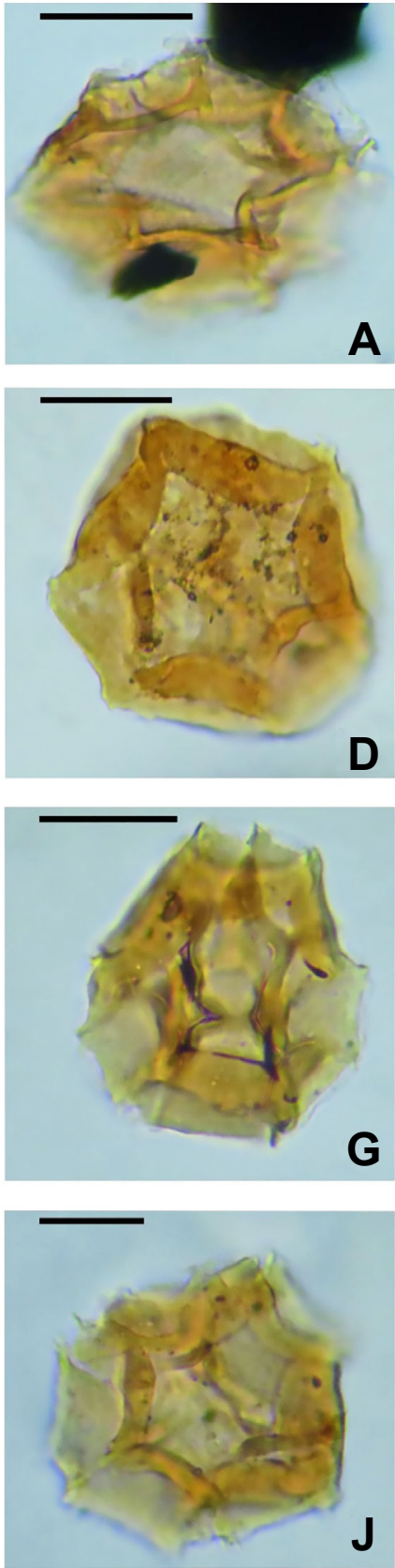

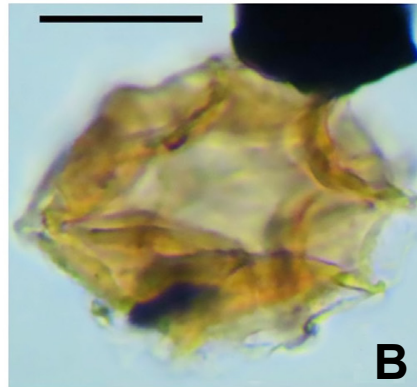

B
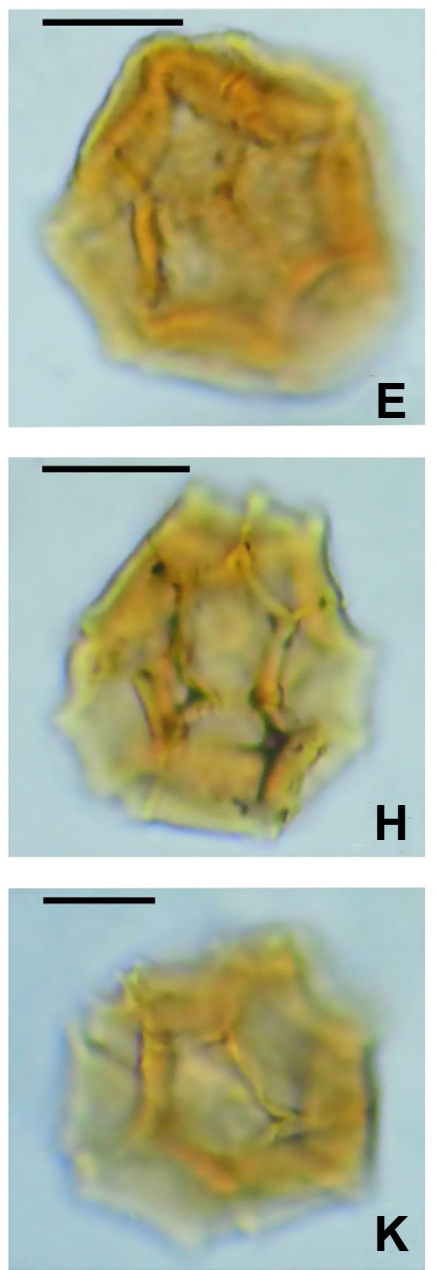
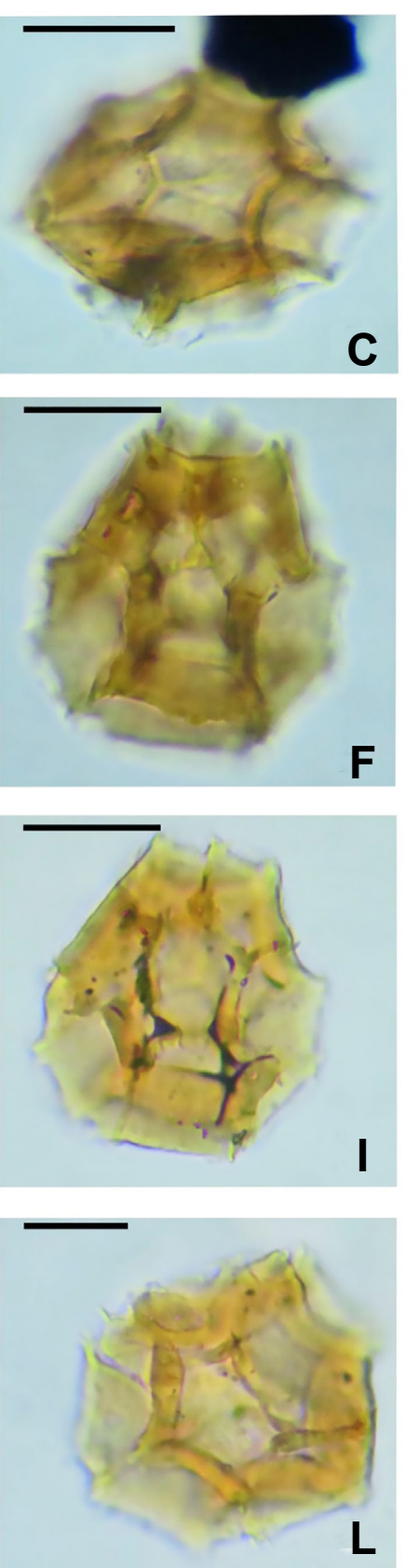

Figure 4. A-L, Retitriletes polygonatus sp. nov. A, D, H, J, distal foci; C, E, F, proximal foci; B, G, I, K, L, median foci. Scale bars = $20 \mu \mathrm{m}$. 

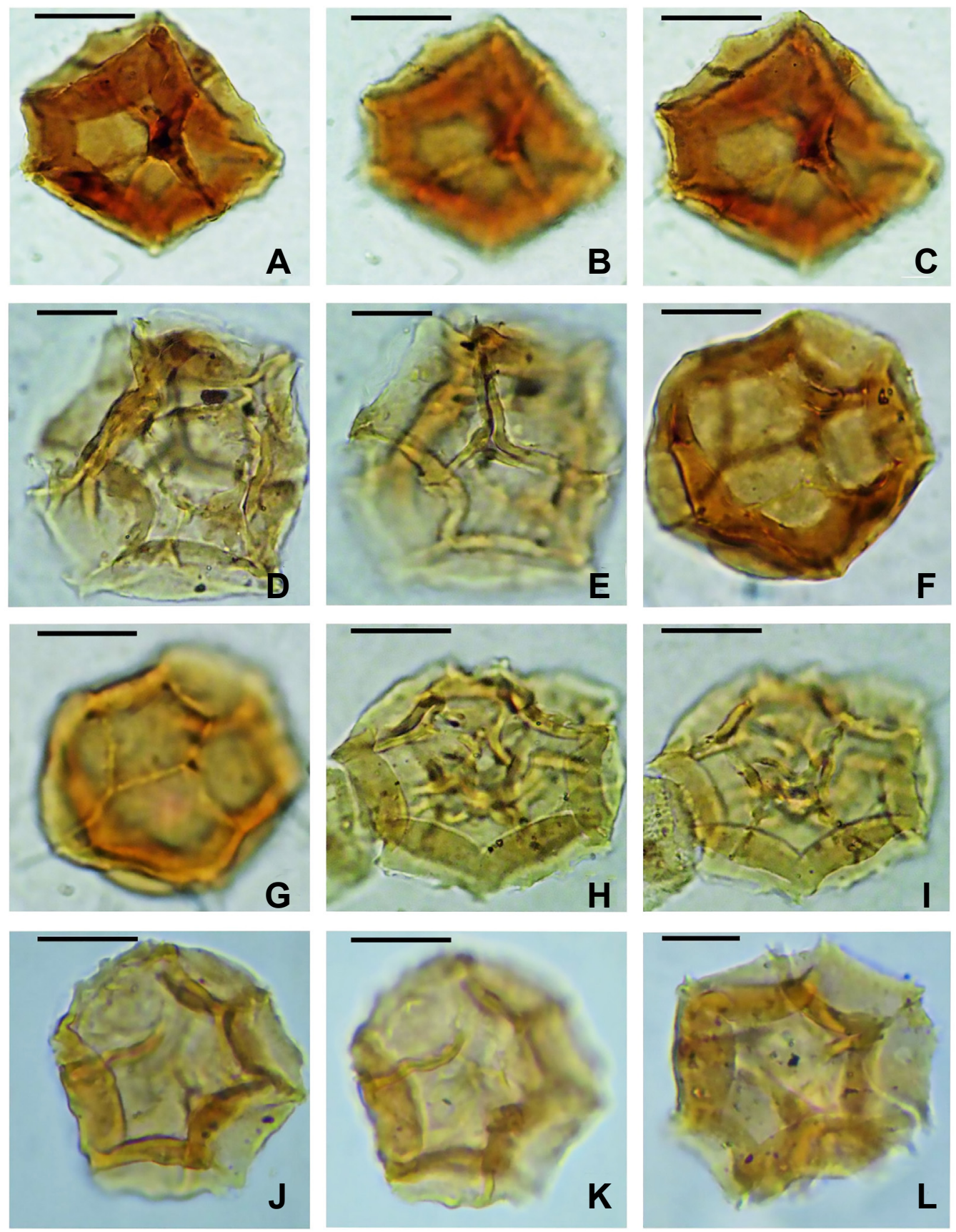

Figure 5. A-L, Retitriletes polygonatus sp. nov. A, D, F, H, J, distal foci; B, E, G, I, L, proximal foci; C, K, median foci. Scale bars = $20 \mu \mathrm{m}$.

Etymology. Latin, Polygonal amb.

Diagnosis. Miospores radial, trilete. Amb pentagonal to hexagonal, sides straight to convex, apices rounded to weakly pointed. Laesurae distinct to moderately indistinct, straight to weakly sinuous, extending to, or nearly to equator, usually marked by a characteristic defined margo (lips 1-2.5 $\mu \mathrm{m}$ wide individually) laevigate proximally, proximo-equatorial region occasionally bearing extension of distal sculpture, reticulate distally and equatorially with thick to narrow, concave - to straight - sided muri, $c a$. 3-5 $\mu \mathrm{m}$ wide, $2-11 \mu \mathrm{m}$ high, and, polygonal to subpolygonal lumina $c a$. 5-13 $\mu \mathrm{m}$ (rarely up to
$15 \mu \mathrm{m})$ in diameter; in some specimens muri are so thin and delicate that sometimes are folded at the margin (Figures $4 \mathrm{~A}, 5 \mathrm{H})$.

Description. Amb pentangular, $55 \mu \mathrm{m}$ in overall equatorial diameter; laesurae \pm indistinct, weakly sinuous, extending to equator, margo (lips $2 \mu \mathrm{m}$ wide individually), sculptured distally with an irregular reticulum comprising anastomosing muri 2-11 $\mu \mathrm{m}$ high, $3 \mu \mathrm{m}$ wide, with concave sides. Lumina polygonal to subpolygonal or irregularly elongate, 9-15 $\mu \mathrm{m}$ in diameter. Proximal surface is laevigate, with an imperfect reticulum proximo-equatorially. 
Dimensions. (16 specimens): Equatorial diameter 32 (55) 65 $\mu \mathrm{m}$ (including sculpture).

Comparison. Retitriletes polygonatus sp. nov. is distinguishable from other species of the genus by its pentagonal to hexagonal amb; wide and high muri; polygonal to subpolygonal or irregularly elongate lumina. This new species differentiated from $R$. facetus (Dettmann) Srivastava, 1975 (p. 58), from south-eastern Australia and R. neofacetus McKellar, 1998 (p. 111-112, pl. 15, figs. 9-14), from the Middle Jurassic of the Surat Basin, Queensland, in possessing a laevigate exoexine. $R$. watherooensis Backhouse, 1978 (p. 24-25, pl. 3, figs. 1-3), from the Late Jurassic-Early Cretaceous of the Pert Basin, Western Australia, is identifiable primarily by very small distal meshed reticulum.

The Surat Basin post-Jurassic species Retitriletes siobhaniae McKellar, 1998 (p. 107-108, pl. 14, figs. 1-9), and R. circolumenus (Cookson \& Dettmann) Backhouse, 1978 (p. 22-23, pl. 2, figs. 7, 8), from the Late Jurassic-Early Cretaceous of the Perth Basin, Western Australia, show subcircular, subelliptical or irregularly elongate lumina and they are proximally laevigate except in contact areas. This new species of Retitriletes differs from $R$. parvireticulatus Backhouse, 1988 (p. 67-68, pl. 9, figs. 15, 16), from the Late Jurassic-Early Cretaceous of the Perth Basin, Western Australia, R. huttonensis McKellar, 1974 (p. 14-15, pl. 5, figs. 7-12), and $R$. rosewoodensis (de Jersey) McKellar, 1974 (p. 14, pl. 5, figs. 4, 5), from the Early-Middle Jurassic of the Surat Basin, by the possession of larger lumina bounded by wider and higher muri on the distal surface. R. austroclavatidites (Cookson) Döring, Krutzsch, Mai \& Schulz, 1963 (p. 16), from the Middle-Late Jurassic of the Germany, can be distinguished by its subcircular to convexly subtriangular amb and possesses smaller lumina bounded by narrow and lower muri. $R$. singhii (Singh) Srivastava, 1972 (p. 32, pl. 27, fig. 10), from the Maestrichtian of Alberta, Canada, is distinguishable by proximal sculpture which is variably developed (irregularly rugulate). The Surat Basin Middle-Late Jurassic species Retitriletes proxiradiatus McKellar, 1998 (p. 102-103, pl. 13, figs. 6-12), is distinguishable by an imperfect, radially oriented proximal reticulum.

Natural botanical affinity. Lycophyte: Raine et al. (2011). Stratigraphic range. Middle Jurassic (Bajocian-BathonianCallovian).

\section{CONCLUSIONS}

Diverse, well-preserved Middle Jurassic palynofloras retrieved from the Dalichai and Baghamshah formations of northern and central Iran comprise both marine and terrestrial palynomorphs. The latter include, inter alia, a new distinct reticulate, lycophyte spore species erected herein as Retitriletes polygonatus sp. nov. The possible restricted stratigraphic cooccurence within the interval examined and distinct morphological features of the new taxon might indicate its utility in regional correlation of the Middle Jurassic strata across north and central Iran.

\section{REFERENCES}

Achilles, H.; Kaiser, H. \& Schweitzer, H.J. 1984. Die rätojurassischen Floren des Iran und Afghanistans. 7. Die Mikroflora der obertriadisch-jurassischen Ablagerungen des Alborz-Gebirges (Nord-Iran). Palaeontographica, Abteilung $B$, 194:14-95.

Alavi, M. 1996. Tectonostratigraphic synthesis and structural style of the Alborz mountain system in northern Iran. Journal of Geodynamics, 21:1-33. doi:10.1016/0264-3707(95)00009-7

Alavi-Naini, M. 1972. Etude geologique de la region de Djam. Geological Survey of Iran, Report, 23:1-293.

Arjang, B. 1975. Die räto-jurassischen Floren des Iran und Afghanistans. 1.Die Mikroflora der räto-jurassischen Ablagerungen des Kermaner Beckens (Zentral-Iran). Palaeontographica, Abteilung B, 152:85-148.

Ashraf, A.R. 1977. Die räto-jurassischen Floren des Iran und Afghanistans. 3. Die Mikrofloren deren der rätischen bis unterkretazischen Ablagerungen Nord Afghanistans. Palaeontographica, Abteilung B, 161:1-97.

Backhouse, J. 1978. Palynological zonation of the Late Jurassic and Early Cretaceous sediments of the Yarragadee Formation, central Perth Basin, Western Australia. Geological Survey of Western Australia, Report, 7:1-53.

Backhouse, J. 1988. Late Jurassic and Early Cretaceous palynology of the Perth Basin, Western Australia. Geological Survey of Western Australia, Bulletin, 135:1-233.

Balme, B.E. 1963. Plant microfossils from the Lower Triassic of Western Australia. Palaeontology, 6:12-40.

Balme, B.E. 1964. The palynological record of Australian Pre Tertiary floras. In: L.M. Cranwell (ed.) Ancient Pacific floras-The pollen story- University of Hawaii Press, Honolulu, p. 49-80.

Bharadwaj, D.C. \& Kumar, P. 1986. Palynology of Jurassic sediments from Iran: 1, Kerman area. Biological Memoirs, 12:146-172.

Bharadwaj, D.C. \& Kumar, P. 1988. Palynology of Jurassic sediments from Iran: 2, Zirab area. Biological Memoirs, 14:55-80.

Couper, R.A. 1958. British Mesozoic microspores and pollen grains, systematic and stratigraphic study. Palaeontographica, Abteilung B, 103:75-179.

Dehbozorgi, A.; Sajjadi F. \& Hashemi, H. 2013. Middle Jurassic palynomorphs of the Dalichai Formation, central Alborz Ranges, northeastern Iran: Paleoecological inferences. Science China Earth Sciences, 56:2107-2115. doi:10.1007/s11430-013-4697-z

Delcourt, A. \& Sprumont, G. 1955. Les spores et grains de pollen du Wealdien du Hainaut. Mémoires de la Société Belge de Géologie, 4:1-73.

Döring, H.; Krutzsch, W.; Mai, D.H. \& Schulz, E. 1963. Retitriletes. In: W. Krutzsch (editor): Atlas der mittel-und jungtertiören dispersen Sporen-und Pollen-sowie der Mikroplanktonformen des nördlichen Mitteleuropas. - Lieferung II, VEB Deutscher Verlag der Wissenschaften, Berlin: 8-18.

Filatoff, J. \& Price, P.L. 1988. A pteridacean spore lineage in the Australian Mesozoic. In: P.A. Jell \& G. Playford (eds.) Palynological and palaeobotanical studies in honour of Basil E. Balme. Memoirs of the Association of Australasian Palaeontologists, 5:89-124.

Fürsich, F.T.; Wilmsen, M.; Seyed-Emami, K. \& Majidifard, M.R. 2009. The Mid-Cimmerian tectonic event (Bajocian) in the Alborz Mountains, Northern Iran: evidence of the break-up unconformity of the South Caspian Basin. Geological Society, London, Special Publications, 312:189-203. doi:10.1144/ SP312.9 
Ghasemi-Nejad, E.; Sabbaghiyan, H. \& Mosaddegh, H. 2012. Palaeobiogeographic implications of Late Bajocian-Late Callovian (Middle Jurassic) dinoflagellate cysts from the Central Alborz Mountains, northern Iran. Journal of Asian Earth Sciences, 43:1-10. doi:10.1016/j.jseaes.2011.08.006

Hassanzadeh, J.; Ghazi, A.M.; Axen, G. \& Guest, B. 2002. Oligomiocene mafic-alkaline magmatism north and northwest of Iran. Evidence for the separation of the Alborz from the Urumieh-Dokhtar magmatic arc. Geological Society of America, Abstracts with Programs, 34:331.

Kimyai, A. 1968. Jurassic plant microfossils from the Kerman region. Bulletin of the Iranian Petroleum Institute, 33:91-111.

Kimyai, A. 1974. Jurassic plant microfossils from Iran. Birbal Sahni Institute of Palaeobotany, Special Publication, 3:1-8.

Krutzsch, W. 1963. Atlas der mittel- und jungtertiären dispersen Sporen- und Pollen-sowie der Mikroplanktonformen des nördlichen Mitteleuropas. Lieferung II. Die Sporen der 12 Anthocerotaceae und der Lycopodiaceae. VEB Deutscher Verlag der Wissenschaften, Berlin, p. 1-141.

Mafi, A.; Ghasemi-Nejad, E.; Ashouri, A. \& Vahidi-Nia, M. 2013. Dinoflagellate cysts from the Upper Bajocian - Lower Oxfordian of the Dalichai Formation in Binalud Mountains (NE Iran): their biostratigraphical and biogeographical significance. Arabian Journal of Geosciences, 7:3683-3692. doi:10.1007/s12517013-0976-4

McKellar, J. 1974. Jurassic miospores from the upper Evergreen Formation, Hutton Sandstone, and basal Injune Creek Group, north-eastern Surat Basin. Geological Survey of Queensland, Publication 361, Palaeontological Paper, 35:1-89.

McKellar, J. 1998. Late Early to Late Jurassic palynology, biostratigraphy and palaeogeography of the Roma Shelf area, northwestern Surat Basin, Queensland, Australia. Unpublished Ph.D. Thesis, University of Queensland, 515 p.

Nabavi, M.H. \& Seyed-Emami, K. 1977. Sinemurian ammonites from the Shemshak Formation of North Iran (Semnan area, Alborz). Neues Jahrbuch für Geologie und Palaeontologie, Abhandlungen, 153:70-85.

Phipps, D. \& Playford, G. 1984. Laboratory techniques for extraction of palynomorphs from sediments. Department of Geology, University of Queensland, Papers, 11:1-29.

Raine, J.I.; Mildenhall, D.C. \& Kennedy, E.M. 2011. New Zealand fossil spores and pollen: An illustrated catalogue. GNS Science Miscellaneous Series No. 4. Retrieved from http://data.gns.cri. $\mathrm{nz} / \mathrm{sporepollen/index.} \mathrm{htm}$

Riding, J.B. \& Thomas, J.E. 1992. Dinoflagellate cysts of the Jurassic system. In: A.J. Powell, (ed.) A stratigraphic Index of Dinoflagellate Cysts. Chapman \& Hall, London, 7-97.

Sajjadi, F.; Hashemi, H. \& Dehbozorgi, A. 2007. Middle Jurassic palynomorphs of the Kashafrud Formation, Koppeh Dagh Basin, northeastern Iran. Micropaleontology, 53:391-408. doi:10.2113/ gsmicropal.53.5.391

Schairer, G.; Seyed-Emami, K. \& Zeiss, A. 1991. Ammoniten aus der oberen Dalichai-Formation (Callov) ostlich von Semnan (SE-Alborz, Iran). Mitteilungen der Bayerische Staatssammlung für Paläontologie Historiche und Geologie, 31:47-67.
Seyed-Emami, K.; Schairer, G. \& Bolourchi, M.H. 1985. Ammoniten aus der unteren Dalichy-Formation (oberes Bajocium bis unteres Bathonium) der Umgebung von Abe-Garm (Avaj, NWZentraliran), Zitteliana, 12:57-85.

Seyed-Emami, K.; Schairer, G. \& Zeiss, A. 1995. Ammoniten aus der Dalichai-Formation (Mittlerer bis Oberer Jura) und der LarFormation (Oberer Jura) N Emamzadeh-Hashem (Zentralalborz, Nordirn). Mitteilungen der Bayerische Staatssammlung für Paläontologie Historiche und Geologie, 35:39-52.

Seyed-Emami, K.; Schairer, G. \& Aghanabati, S.A. 1997. Ammoniten aus der Baghamshah Formation (Callov, Mittlerer Jura), NW Tabas (Zentraliran). Mitteilungen der Bayerischen Staatssammlung für Paläontologie und Historische Geologie, 37:24-40.

Seyed-Emami, K.; Schairer, G.; Aghanabati, S.A.; Fürsich, F.T.; Senoebari-Daryan, B. \& Majidifard, M.R. 1998. Cadomites aus der unteren Baghamshah Formation (Ober bathon, Mittlerer Jura) SW Tabas (Zentraliran). Mitteilungen der Bayerischen Staatssammlung für Paläontologie und Historische Geologie, 38:111-119.

Seyed-Emami, K. 2003. Triassic in Iran. Facies, 48:91-106. doi:10.1007/BF02667532

Seyed-Emami, K.; Fürisch, F.T.; Wilmsen, M.; Majidifard, M.R. \& Skekarifard, A. 2008. Lower and Middle Jurassic ammonoids of the Shemshak Group in Alborz, Iran and their palaeobiogeographical and biostratigraphical importance. Acta Geologica Polonica, 53:237-260. doi:10.4202/app.2008.0206

Srivastava, S.K. 1972. Systematic description of some spores from the Edmonton Formation (Maestrichtian), Alberta, Canada. Palaeontographica, Abteilung B, 139:1-46.

Srivastava, S.K. 1975. Microspores from the Fredericksburg Group (Albian) of the southern United States. Paléobiologie Continentale, 6:1-119.

Steiger, R. 1966. Die Geologie der West-Firuzkuh-Area (Zentral Elburz/Iran). Geologisches Institute der Eidgenosischen Technischen Hochschule und der Universitat Zürich, 68:1-145.

Stöcklin, J. 1968. Structural history and tectonics of Iran; a review. American Association of Petroleum Geologists Bulletin, 52:1229-1258.

Stöcklin, J. 1974. Possible ancient continental margins in Iran. In: C.A. Burk \& C.L. Drake (eds.) The Geology of Continental Margins. Springer, Berlin.

Sussli, P.E. 1976. The geology of the lower Haraz Valley Area. Centeral Alborz, Iran. Geological Survey of Iran, Report, 38:1118.

Traverse, A. 2007. Palaeopalynology. 2nd ed. Dordrecht, London, Springer, $813 \mathrm{p}$.

Received in August, 2014; accepted in June, 2015. 
Appendix 1. List of palynomorph taxa in alphabetic order.

\section{MIOSPORES}

Aequitriradites norrisii Backhouse, 1988

Alisporites grandis (Cookson) Dettmann, 1963

Alisporites lowoodensis de Jersey, 1963

Alisporites similis (Balme) Dettmann, 1963

Alisporites microsaccus (Couper) Muir, 1964

Anapiculatisporites dawsonensis Reiser \& Williams, 1969

Anapiculatisporites sp. cf. A. pristidentatus Reiser \& Williams, 1969

Annulispora densata de Jersey, 1959

Aratrisporites fischeri (Klaus) Playford \& Dettmann, 1965

Araucariacites australis Cookson ex Couper, 1953.

Biretisporites sp.

Callialasporites dampieri (Balme) Sukh Dev, 1961.

Callialasporites minus (Tralau) Guy, 1971

Callialasporites trilobatus (Balme) Sukh Dev, 1961

Camarozonosporites ramosus (de Jersey) McKellar, 1974

Cerebropollenites macroverrucosus (Thiergart) Schulz, 1967

Chasmatosporites apertus (Rogalska) Nilsson, 1958

Chasmatosporites major Nilsson, 1958

Concavissimisporites punctatus (Delcourt \& Sprumont) Brenner, 1963

Concavissimisporites verrucosus Delcourt \& Sprumont emend. McKellar, 1998

Converrucosisporites parvitumulus McKellar, 1998

Converrucosisporites pricei McKellar, 1998

Contignisporites burgeri Filatoff, McKellar \& Price in Filatoff \& Price, 1988

Classopollis simplex (Danzé-Corsin \& Laveine) Cornet \& Traverse, 1975

Classopollis sp.

Cyathidites australis Couper, 1953

Cyathidites minor Couper, 1953

Cycadopites crassimarginis (de Jersey) de Jersey, 1964

Cycadopites follicularis Wilson \& Webster, 1946

Cycadopites sp. cf. C. follicularis Wilson \& Webster, 1946

Cycadopites granulatus (de Jersey) de Jersey, 1964

Deltoidospora $\mathrm{sp}$

Densoisporites velatus Weyland \& Krieger emend. Karsnova, 1961

Dictyophyllidites harrisii Couper, 1958

Dictyophyllidites mortonii (de Jersey) Playford \& Dettmann, 1965

Dictyotosporites complex Cookson \& Dettmann, 1958

Foveosporites pseudoalveolatus (Couper) McKellar, 1998

Gleicheniidites senonicus Ross emend. Skarby, 1964

Ischyosporites crateris Balme, 1957

Klukisporites variegatus Couper, 1958

Klukisporites lacunus Filatoff, 1975

Laevigatosporites ovatus Wilson \& Webster, 1946

Limbosporites lundbladii Nilsson, 1958

Limbosporites antiquus (de Jersey) de Jersey \& Raine, 1990

Limbosporites denmeadii (de Jersey) de Jersey \& Raine, 1990

Limbosporites sp. A of McKellar, 1998

Matonisporites crassiangulatus (Balme) Dettmann, 1963

Murospora florida (Balme) Pocock, 1961

Neoraistrickia truncata (Cookson) Potonié, 1956

Neoraistrickia taylorii Playford \& Dettmann, 1965

Neoraistrickia parvibacula McKellar, 1998

Osmundacidites senectus Balme, 1963

Osmundacidites wellmanii Couper, 1953

Perotrilites granulatus Couper emend. Evans, 1970

Phlebopterisporites equiexinus (Couper) Juhász, 1979

Platysaccus queenslandi de Jersey, 1962

Podocarpidites astrictus Haskell, 1968

Podocarpidites ellipticus Cookson, 1947

Polycingulatisporites crenulatus Playford \& Dettmann emend. McKellar, 1974

Retitriletes austroclavatidites (Cookson) Döring, Krutzsch, Mai \& Schulz, 1963

Retitriletes clavatoides (Couper) Döring, Krutzsch, Mai \& Schulz, 1963

Ricciisporites tuberculatus Lundblad, 1954

Rugulatisporites neuquenensis Volkheimer, 1972

Sellaspora asperata (Dettmann) emend. McKellar, 1998

Sellaspora passa McKellar, 1998

Staplinisporites caminus (Balme) Pocock, 1962

Striatella seebergensis Mädler, 1964

Striatella balmei Filatoff \& Price, 1988 
Striatella sp. cf. S. balmei Filatoff \& Price, 1988

Striatella scanica (Nilsson) Filatoff \& Price, 1988

Striatella parva (Li \& Shang) Filatoff \& Price, 1988

Todisporites major Couper, 1958

Todisporites minor Couper, 1958

Toripustulatisporites kainophyticus Krutzsch, 1959

Trilites volkheimeri (Filatoff) Sajjadi \& Playford, 2003

Trilobosporites antiquus Reiser \& Williams, 1969

Verrucosisporites major (Couper) Burden \& Hills, 1989

Verrucosisporites varians Volkheimer, 1972

DINOFLAGELLATE CYSTS

Adnatosphaeridium caulleryi (Deflandre) Williams \& Downie, 1969

Carpathodinium predae (Beju) Drugg, 1978

Cleistosphaeridium sp.

Cometodinium jurassicum Poulsen, 1996

Ctenidodinium combazii Dupin, 1968

Ctenidodinium ornatum (Eisenack) Deflandre, 1938

Compositosphaeridium polonicum (Gorka) Erkmen \& Sarjeant, 1980

Conosphaeridium striatoconum (Deflandre \& Cookson) Cookson \& Eisenack, 1969

Gonyaulacysta jurassica (Deflandre) Norris \& Sarjeant, 1965

Meiourogonyaulax valensii Sarjeant, 1966

Mendicodinium groenlandicum (Pocock \& Sarjeant) Davey, 1979

Nannoceratopsis sp.

Pareodinia ceratophora Deflandre, 1947

Valensiella ovulum (Deflandre) Eisenack, 1963

ACRITARCHA

Circulisporites parvus de Jersey emend. Norris, 1965

Micrhystridium spp.

Veryhachium sp.

FORAMINIFERAL TEST LINING 